\title{
BCR/ABL1 Fusion Protein with ABL1 NP_005148.2:p.G398R
}

National Cancer Institute

\section{Source}

National Cancer Institute. BCR/ABL1 Fusion Protein with ABL1 NP 005148.2:p.G398R.

NCI Thesaurus. Code C130231.

A fusion protein encoded by the BCR/ABL1 fusion gene with a mutation located in exon 7 of the ABL1 gene. This protein is comprised of the $\mathrm{N}$-terminus of the breakpoint cluster region protein fused to almost the entire tyrosine-protein kinase ABL1 protein where the glycine at position 398 of the ABL1 protein has been replaced by arginine. 